\title{
Feminist Distopyalarda Tahakküm ve Direnişin Temsili: Damızlık Kızın Öyküsü Dizi Film Örneği*
}

\author{
The Representation of Domination and Resistance in Feminist Dystopias: \\ The Case of The Handmaid's Tale Tv Series
}

Dilan Tüysüz, Görsel İletişim Tasarımı Bölümü, Aydın Adnan Menderes Üniversitesi

\begin{abstract}
Özet
Geleceğe yönelik düzen tasarımlarını iki kutup bağlamında düşünmek mümkündür. Buna göre bir tarafta ütopya, diğer tarafta ise distopya yer almaktadır. Ütopyalar ideal gelecek kurgusu yaparken; distopyalar ise karanlık ve kaygı verici bir çerçeve çizer. İkisi de düşsel nitelik taşımakla birlikte, gerçeklikten kopuk değildir. Ütopyanın iyimser öngörüleri de distopyanın karamsar korkuları da her zaman gerçek dünya ile bağlantılı olmuştur. Bu çalışmanın konusunu olușturan distopik anlatılar, mevcut toplumsal düzendeki kusurlara dikkat çeken ve bu kusurlar ortadan kaldırılmadığı takdirde meydana gelebilecek olumsuzlukları gösteren uyarılar olarak değerlendirilmektedir. Bununla birlikte distopyaların erkek egemen bir tür olduğu ve dolayısıyla eril bakış açısı taşıdığı unutulmamalıdır. Yirminci yüzyılın sonlarında ortaya çıkan ve kadın yazarlar tarafından kaleme alınan feminist distopya ise, odak noktasına kadını koyan ve erkek egemen düzeni eleștiren anlatılardır. Bu çalıșma, feminist distopya örneklerinin 'geleceğe dair paranoyak tahminler' olduğu görüşüne karşı çıkarak, bu tür anlatıları 'var olan erkek egemen düzenin muhafazakâr gerçekliğinin alegorileri' şeklinde kabul etmektedir. Bu bağlamda feminist distopya türünün temsilcilerinden kabul edilen Margaret Atwood'un 1985 yllında yazdığı The Handmaid's Tale romanından aynı adla uyarlanan televizyon dizisi ele alınmıştır. Ataerkil düzene eleştirisini distopya türü üzerinden yapan dizide, egemen düzenin tahakküm araçlarının ve tabi olanların direniş olanaklarının nasıl temsil edildiği nitel içerik analiz yöntemiyle incelenmiștir.
\end{abstract}

Anahtar Sözcükler: Feminist distopya, Damızlık Kızın Öyküsü, tahakküm, direniș.

Akademik disiplin(ler)/alan(lar): Sinema, televizyon.

\begin{abstract}
It is possible to evaluate future governing models as binary oppositions. In this framework there is a utopia on one hand and a dystopia on the other. While utopias set out an ideal future; dystopias draw a dark and worrying picture. Though both of them are imaginary, they are not detached from reality. Optimistic predictions of utopia and pessimistic fears of the dystopia have always been linked to the real world. Dystopic narratives constituting the subject of this study are considered as warnings that draw attention to the defects in current social order and reveal the adversities that may occur if these defects are not eliminated. Nonetheless, it should be kept in mind that dystopias are male-dominated and therefore have a masculine point of view. Feminist dystopias that emerged in the late twentieth century were written by female writers. As a result, such feminist utopias present narratives in which women are placed at the centre of discussion, and thus, criticize patriarchy. This study opposes the view that the examples of feminist dystopia are 'paranoid predictions of the future' and accepts such narratives as 'allegories of the conservative reality of the existing male-dominated order'. In this context, the television series adapted from Margaret Atwood's 1985 novel The Handmaid's Tale is discussed as one of the representatives of the feminist dystopia genre. This paper explores the representation of how a hegemonic order uses tools of domination and the possibilities of resistance in the series, which criticizes the patriarchal order, through elements of the dystopia genre by conducting a qualitative content analysis.
\end{abstract}

Keywords: Feminist dystopia, The Handmaid's Tale, domination, resistance.

Academical disciplines/fields: Cinema, television.

\footnotetext{
* Bu çalışma 10-12 Ekim 2019 tarihleri arasında Kuzey Kıbrıs Türk Cumhuriyeti Lefkoşa'da düzenlenen 7. Uluslararası Toplumsal Cinsiyet Çalışmaları
} Konferansı'nda özet bildiri olarak sunulmuștur.

- Sorumlu Yazar: Dilan Tüysüz, Görsel İletișim Tasarımı Bölümü, Aydın Adnan Menderes Üniversitesi.

- Adres: Aydın Adnan Menderes Üniversitesi Merkezi Derslikler İletişim Fakültesi C/Blok Kat: 3 Merkez/Aydın.

- e-posta: dilan.tuysuz@adu.edu.tr

- ORCID: 0000-0002-5887-9519

- Çevrimiçi yayın tarihi: 14.12 .2021

- doi: $10.17484 /$ yedi.793786 


\section{Giriş}

İnsanın içinde yaşadığı toplumun ve zamanın ötesine bakarak, geleceğe yönelik düzen tasarımları yapma ihtiyacı eski medeniyetlere kadar uzanmaktadır. Eşit ve adil yaşama hayali bütün toplumlarda her zaman karşılaşılan bir ideal olmuştur. Kısaca 'ideal toplum tasarısı' olarak tanımlanabilecek ütopya kavramı, ismini 16. yüzyılda Thomas More'un aynı adlı eserine borçludur ve kendisinden sonra gelen tüm toplum tasarıları bu isimle anılmıştır. Bununla birlikte, ütopik kurguların More'un döneminden çok daha eskiye, antik çağa kadar dayandığı bilinmektedir. Ütopyaların 5 bin yıllık bir geçmişe sahip olduğunu belirten Sadık Usta'ya göre, ütopyanın yolculuğunu Sümer, Mısır, Yunanistan, Roma, Çin, Hindistan, Ortadoğu ve Avrupa'daki medeniyetlerde takip etmek mümkündür (2005, s. 7).

Kökenleri ütopya kadar eskiye uzanmayan distopyalar ise genellikle ütopyanın karșıtı, kötü kardeși ya da 'yoldan çıkmış' versiyonu olarak nitelendirilmektedir. Distopya yerine karşıütopya kavramını kullanan Krishan Kumar, ütopya ve karşıütopyanın karşılıklı bağımlılı̆̆ına rağmen birbirlerinin anti-tezi olduğuna işaret etmektedir. Yazara göre iki kavram arasındaki ilişki simetrik ya da eşit değildir. Kumar, ütopya ve karşıütopyanın zıt kavramlar olduğunu vurgular (2006, s. 172). Karşıütopya malzemesini ütopyadan almakta ve onu yeniden kurmaktadır. Akıl, bilim, teknolojik gelișmeler, yeni bulușlar ve modern fikirler ütopyaların gelişimine yol açarken; aynı kavramlar zamanla insanlığı bekleyen aydınlık akıbete götürmeyecek, aksine karanlık bir geleceğe yol açacak unsurlar olarak distopyalarda karşılığını bulmuştur. Aynı malzemelerle ütopyalar hayal kurmuş, distopyalar ise kâbuslar yaratmıştır.

Bu çalışmada ilk olarak önemli edebi örnekler üzerinden ütopya ve distopyaların genel özellikleri değerlendirilmiş ve her iki kurgusal düzenin birbiri içine nasıl geçmiş olduğu tartışılmıştır. Geleneksel ütopyaların aksine cinsiyetler arasındaki eşitsizliği ortadan kaldırmaya çalışan, kadını ve erkeği aynı hak ve sorumluluklara sahip eşit bireyler olarak kabul eden feminist ütopyalara dair bilgi verildikten sonra ise feminist distopya olarak nitelendirilen anlatılar ele alınmıştır. Her ütopyanın içinde distopya, her distopyanın içinde ise ütopya saklı olduğu fikrinden yola çıkan bu çalışma, distopik sistemlerdeki baskıcı uygulamalara karşı direnişin olanaklı ve olası olduğunu kabul etmektedir. Bu bağlamda önemli feminist distopya örnekleri arasında kabul edilen Margaret Atwood'a ait Damızlık Kızın Öyküsü (The Handmaid's Tale, 1985) romanından uyarlanan aynı isimli televizyon dizisi incelenmiştir. İlk sezonu 2017 yılında yayınlanmaya başlayan ve üç sezondur devam etmekte olan dizideki kurgusal evrende gerçekleşen tahakküm uygulamaları ve buna karşılık olarak gerçekleștirilen direniş eylemleri değerlendirilirken nitel içerik analiz yöntemi uygulanmıştır. Yazılı ve görsel metinlerde temsil edilen sosyal gerçekliğin açıklanması sürecindeki bilgi üretme yollarından biri olan nitel içerik analizi yöntemi, söz konusu sosyal gerçeklik insan zihninden bağımsız olamayacağı için, bilginin araştırmacı tarafından örülerek yapılandırılması varsayımına dayanmaktadır (Özdemir, 2010, s. 339). Bu bakımdan, çalışmada ele alınan distopik kurgu örneği Damızlık Kızın Öyküsü'nde inşa edilen toplumsal gerçekliğin incelenmesinde nitel içerik analizi yöntemi tercih edilmiştir. Bu bağlamda önce dizideki erkek egemen Gilead Cumhuriyeti'nde dinin, çeşitli tören ve seremonilerin, kadınların işlevlerine göre sınıflandırılmasına dayanan toplumsal düzenin, tek tip kıyafet, yeniden isimlendirme gibi uygulamaların ve gözetim-denetim mekanizmalarının tahakküm araçları olarak nasıl kullanıldığı irdelenmiştir. Çalışmanın devamında oldukça katı kurallara sahip bir sistemdeki direniş olanakları araştırılarak dizinin ana karakterinin hikâye anlatıcılığı, kadın karakterlerin direnişe yönelik eylemleri ve dizideki kadın dayanışmasına dayalı örgütlenmeler değerlendirilmiştir.

Damızlık Kızın Öyküsü dizisinin bu çalışma açısından önemini, dizinin yayına başladığı dönemde Amerikan toplumundaki kültürel, politik ve sosyal gelişmelerle ve özellikle iki binli yıllar sonrasında Amerikan sinemasında ağırlık kazanan güçlü kadın temsilleriyle ilişki kurarak açıklamak mümkündür. Amerikan sinemasının son dönem örneklerine bakıldığında güçlü ve bağımsız kadın temsillerine dair örneklerin önemli ölçüde arttığı gözlemlenmektedir. Wonder Woman (2017), Captain Marvel (2019) gibi filmlerdeki süper kadın kahramanlar ile Ölümcül Deney (Resident Evil, 2002) ve Açlık Oyunları (Hunger Games, 20122015) serilerindeki ana kadın karakterler Amerikan sinemasındaki bu eğilime verilebilecek başlıca örnekler arasında yer almaktadır. Son dönemdeki popüler televizyon dizileri de tıpkı beyazperdedeki gibi fiziksel ve zihinsel becerileriyle öne çıkan, kurtarılmayı beklemeyen kadın karakterlere yer vermeye başlamıştır. Vikingler (Vikings, 2013- ) ile Taht Oyunları (Game of Thrones, 2011-2019) dizilerindeki kadın karakterler bağımsız ve güçlü kadın temsilleri açısından önemli örneklerdir. Bu doğrultuda, Damızlık Kızın Öyküsü dizisindeki kadın temsillerini, Amerikan sinema ve televizyon yapımlarındaki söz konusu feminist rüzgârı dikkate alarak düşünmek gerekmektedir.

Film veya dizi gibi kültürel ürünlerin, üretildiği toplumun sosyal ve siyasal yapısından bağımsız düşünülmemesi gerekliliği hatırlandığında, dizinin yayınlanmaya başladığı dönemde Amerika Birleşik Devletleri'nde başlayan ve diğer ülkelere yayılan feminist hareketler de göz önüne alınmalıdır. Cinsel saldırı 
ve cinsel tacizle mücadele etmek ve cinsel taciz mağdurlarına yasal destek sağlamak amacıyla 2017 yılında \#MeToo etiketiyle sosyal medyada başlayarak popülerleşen ve sonrasında Time's Up kampanyasıyla devam eden bu hareketler, ilk olarak sinema endüstrisi içinde başlamış olsa da başka sektörlerdeki istismar mağdurlarını ve cinsiyet eşitsizliğine uğrayan tüm kadınları kapsayacak şekilde genişlemiştir. Aynı sene, misyonunu "Şiddet içermeyen direniş ve kendi kaderini tayin etme, haysiyet ve saygı tarafından yönlendirilen kapsayıcı yapılar inșa etme yoluyla baskı sistemlerini ortadan kaldırmak" (About Us Mission and Principles, 2020) olarak belirleyen Women's March gösterileri yapılmıştır. Başkent Washington'da başlayan ve ABD Başkanı Donald Trump’ın baskıcı politikalarına yönelik protestolar içeren Women's March, kadın liderliğinde bir hareket olarak kendisini tanımlamaktadır. Buna göre, Damızlık Kızın Öyküsü’nün, Atwood'un romanının yayınlandığı 1985 tarihinden otuz iki yıl sonra neden bu dönemde uyarlanmış olduğunu bahsedilen toplumsal gelișmeleri² dikkate alarak düşünmek önem kazanmaktadır.

\section{2. Ütopya/Distopya: Hayal/Kâbus}

Ütopyacı düşüncenin ilk örnekleriyle sözlü edebiyat geleneğine ait mitolojik öykülerde ve efsanelerde karşılaşılmaktadır. Sümerler'in Altın Çağ miti, bolluk ve barış içinde yaşanan, kötülüklerin olmadığı bir dönemi anlatmaktadır. Tanrı katına ulaşma niyetiyle yapılan Babil Kulesi'nin Tanrı'yı kızdırmasıyla sona eren Altın Çağ, daha sonrasında özlemle hatırlanan ve ütopya olarak nitelendirilen bir dönem haline gelmiştir.

Benzer bir ütopik çağ, Antik Yunan'da M.Ö. 7. Yüzyılda Hesiodos tarafından yazılan İşler ve Günler'deki Soylar Efsanesi'nde karşımıza çıkmaktadır. Hesiodos'un insanlık tarihini anlattığı bu efsaneye göre, Tanrı Kronos tarafından yaratılan ölümlü insanların ilk ırkı, Tanrılar gibi yaşayan, kaygısız, rahat, acısız, dertsiz, ihtiyarlamayan ve bereketli topraklarda yaşayan Altın Soylular'dır (2018, s. 53). Ancak devamında yaratılan Gümüş Soylular, Tunç Soylular, Yarı Tanrı Kahramanlar ve Demir Soyluların kurduğu toplumsal düzen, her soya adını veren madenin değer sıralamasından da anlaşılacağı üzere, bir önceki dönemden daha kötüye doğru bir gidişi ima etmektedir.

Sümerlerin ve Antik Yunan'ın Altın Çağ'ındaki ortak nokta, iki ütopik tasvirin de geçmişe, yaşanmış ve sona ermiş bir zamana yönelik olmasıdır. Sonrasında karşılaşılan ütopya anlatılarında ise mevcut düzenin iyileştirilmesine, dolayısıyla geleceğe yönelik bir arzunun yer aldığı görülmektedir. Böylece ütopya kavramı, bir zamanlar var olmuş toplumsal düzenden, hayal edilen ancak hiçbir yerde bulunmayan bir toplum şekline işaret eder hale gelmiştir. Buna göre ütopik anlatıların, arzu edilen toplumun oluşturulması için elzem olan koşullar hakkında çerçeve çizdiği söylenebilir.

Ütopik kurguların önemli örneklerinden biri Platon'un ideal devletin nasıl olması gerektiğini anlattığı felsefi eseri Devlet'dir. Doğru toplum yönetimi için uygulanması gereken yasa ve düzenlemelere dair tasarıları kaleme alan Platon, tek tek bireylerin değil 'genel'in mutluluğunu sağlayacak ilkeleri saptamıştır. Platon'un çerçevesini çizdiği ideal devlet modelinin, kendisinden sonra gelen ütopyacı tasarılar için referans noktası oluşturduğu kabul edilmektedir. Frank ve Fritzie Manuel, ütopya tarihi üzerine detaylı bir çerçeve çizdikleri Utopian Thought in the Western World isimli çalışmalarında bu konuya değinerek, Platoncu ütopya anlayışının ölmediğini, sonraki nesillerin ütopyacı fantezilerinde kılık değiştirerek yeniden doğduğunu belirtmektedir (1979, s. 72). Platon'un Devlet'inden yüzyıllar sonra yazılan ve Platon'un ideal toplum tasarısını referans alan bu ütopyacı fantezilerden biri de Thomas More'un ütopya kelimesini literatüre kazandırdığı Ütopya eseridir. Krishan Kumar'a göre More, sadece 'ütopya' kelimesini icat etmemiş, yeni bir edebi form ve daha önemlisi "İnsani ve toplumsal dönüşümün olanaklarına yönelik yeni ve geniş kapsamlı bir anlayış" ortaya koymuştur (2006, s. 46).

More'un eseriyle birlikte anılması gereken diğer ütopik kurgular arasında, Tommaso Campanella'nın 1602 yılında yazdığı Güneş Ülkesi ile Francis Bacon'a ait 1626 tarihli Yeni Atlantis yer almaktadır. Söz konusu ütopik kurgularda mükemmel ve neredeyse kusursuz bir sistem iddiası söz konusudur. Bu sistemin sorunsuz işlemesi için tüm aksaklıkların, eksiklerin giderilmesi ve inşa edilen sistemin dengesini ve uyumunu bozabilecek potansiyel tehditlerin ortadan kaldırılması şarttır. Bu nedenle herkes, oluşturulan düzene uymalıdır. Ancak tasarlanan 'ideal düzen'in sağlanması ve sürdürülmesi için koyulan katı kurallar, zaman içinde baskıcı bir yönetim anlayışının doğmasına ve bireysel özgürlüklerin ihlal ve ihmal edilmesine yol açma tehlikesini taşımaktadır. Dolayısıyla her ütopya tasarımı aslında totalitaryen bir tasarıdır (Yumuşak, 2012, s. 65). Farklılığın ve karşıt görüşlerin dışlanmasına dayanmaktadır. Buna göre, toplumu eşit ve adil biçimde yönetmek arzusuyla oluşturulmuş sistemlerin, kaygan bir zemin üzerine inșa edildiği

${ }^{2}$ Kurgusal Gilead Cumhuriyeti ile ABD arasındaki benzerliklerin karşılaştırıldığı detaylı bir çalışma için bkz: Greene, 2019, s. 51-58. 
anlaşılmaktadır ve söz konusu ütopik düzenle diktatörlüğe dayalı yönetim arasında ince bir çizgi bulunmaktadır. Bu durum bizi ütopyanın kötücül ikizine, yani distopya kavramına götürmektedir.

Distopyayı, ütopyanın tamamen zıddı olarak düşünmemek gerekmektedir. Ütopya, toplumdaki herkes için ideal bir düzen şeklinde tanımlanıyorsa; ütopya/distopya zıtlığına dayanan bir bakış açısına göre distopya da toplumu oluşturan tüm sınıflar, ırklar, cinsiyetler ve dinler için kötü ve korkunç bir düzen anlamına gelecektir. Oysa genellikle belirli bir sınıfın, ırkın, cinsiyetin ve dinin egemen olduğu distopyalar, sadece geri kalanlar için kötüdür. Distopik eserlerde, totaliter hükümetlerin kurduğu yeni düzen, bu düzenin egemenleri tarafından ütopya olarak nitelendirilebilir. Totaliter rejimler yürürlüğe koydukları eskisinden farklı kural ve uygulamalarla ideal bir düzen yarattıklarını ya da yaratma çabasında olduklarını iddia eder. $\mathrm{Bu}$ bakımdan distopya "Yanlış yönde gitmiş bir ütopya veya toplumun belli bir kısmı için iş gören bir ütopyadır" (Gordin, Tilley ve Prakash, 2017, s. 8). Distopik kurgular, ideal toplum düzeni hayalinin imkânsızlığı üzerine kurulan anlatılardır. Toplumu mükemmelliğe götürdüğü düşünülen ilke ve kurallarla inşa edilen ütopyaların, içerdiği çelişkiler nedeniyle eninde sonunda söz konusu toplumun tamamı ya da bir bölümü için mutsuzluğa ve kötülüğe yol açacağı fikri, her distopyanın ön kabulüdür.

Distopya kelimesi ilk olarak 1868 yılında, John Stuart Mill tarafından Avam Kamarası'nda yaptığı bir konuşmada, yani ütopya kavramının Thomas More tarafından ortaya atılmasından yaklaşık üç yüz yıl sonra kullanılmıștır (Roth, 2005, s. 230). Bununla birlikte en önemli distopya örneklerinin, 1920'li yıllardan sonra ortaya çıktığını söylemek mümkündür. İki dünya savaşının, diktatörlük rejimlerinin ve yıkımların ardından, ütopyalarda vaat edilen ideal toplum düzeninin gerçekleşme ihtimali olmadığının anlaşılması, dönemin yazar ve düşünürlerini etkilemiştir.

Rus yazar Yevgeni İvanoviç Zamyatin'in 1927 yılında yayınlanan Biz adlı eseri, önemli ilk distopik kurgulardan biri olarak kabul edilmektedir. Kitap, Bolşevik Devrimi'nin özgürlük, eşitlik ve adalet vaadine rağmen, bu yeni düzenin totaliter bir rejime dönüşme tehlikesine dair uyarı niteliği taşımaktadır. Biz, yazıldığı tarihsel dönem bakımından komünizm eleştirisi olarak kabul edilirken, İngiliz yazar Aldous Huxley'in 1932 tarihli Cesur Yeni Dünya adlı eseri ise kapitalizm ve tüketim toplumunun neden olabileceği olumsuzluklara dikkat çekmektedir. Kitabında kurguladığı sistemin çok uzak olmayan gelecekte gerçeğe dönüșme ihtimaline dikkat çekmesi bakımından Huxley'nin, karamsar bir bakıș açısına sahip olduğu görülmektedir. En az onun kadar karamsar bir başka dünya tasviri Okyanusya adlı ülkedeki, katı bir gözetim ve denetim modeli üzerine kurulu totaliter bir sistemi anlatan George Orwell'e ait 1984 romanında karşımıza çıkmaktadır. Romanda, gözetim üzerine inşa edilmiş bir sistem söz konusudur. İktidar, kendisi aleyhine gelişebilecek her türlü potansiyel eleştiri ve muhalefeti önlemek amacıyla tüm vatandaşlarını kamusal ve özel alanda izleyerek bireyler üzerinde baskı kurmaktadır.

Karşıt kutuplarda konumlandırılıyor olsalar da ütopik ve distopik kurguların ortak noktalara sahip olduğunu söylemek mümkündür. Her iki toplumsal düzende de sistemin devamı için bireylerin kurallara itaat etmesi şarttır. Ancak bu itaatin ütopyalarda gönüllü bir şekilde gerçekleștiği varsayılırken, distopyalar bunun için baskı ve gerektiğinde zor kullanmaktadır. Ütopya ve distopyalar arasındaki bir diğer ortaklık ise bireysel özgürlükler meselesidir. Her iki toplumsal kurguda da devletin düzeni ve devamlılığını korumak adına bireyselliklerin göz ardı edildiği görülmektedir. Ütopyaların ve distopyaların vatandaşları temel özgürlüklere sahip değildir, 'biz'in selameti için 'ben' feda edilmiştir. Ütopyaların eninde sonunda distopyaya dönüşme riski taşımasının temelinde bu durum yatmaktadır. Toplumdaki herkesin çıkarını koruyacak ve mutluluğunu sağlayacak bir sistem oluşturma olasılığının imkânsıza yakın olduğu göz önüne alınırsa, ütopyaların barındırdığı ikilem ortaya çıkmaktadır. Vurgulamak gerekirse ütopyalar, içinde distopya potansiyeli taşıyan anlatılardır.

Damızlık Kızın Öyküsü romanının yazarı Margaret Atwood da ütopya ve distopyanın bu özelliğine dikkat çekmiş ve iki kavramın birleşimi olarak üstopya terimini icat etmiştir. Yazara göre ütopya ve distopya, yin yang felsefesine benzer şekilde, örtük olarak birbirinin tezahürünü içermektedir (2014, s. 77). Bir kişinin, grubun ya da toplumun ütopyası, başka bir kişinin, grubun ya da toplumun distopyası olabilir. Başka bir deyişle her ütopya kendi içinde distopyasını barındırır ve her distopya ütopik bir niteliğe sahiptir. Bu doğrultuda çalıșmanın konusunu oluşturan feminist distopyaları, aynı zamanda eril ütopyalar olarak nitelendirmek mümkündür.

\section{Feminist Ütopya ve Feminist Distopya}

Başlıca örneklerinden bahsedilen ütopik kurguların, erkek yazarların hakimiyetinde bir tür olarak geliștiği görülmektedir. Erkek egemen toplum düzenindeki cinsiyet eşitsizliklerini, kadına yönelik baskıları eleştiren ve kadın yazarlar tarafından kaleme alınan ilk feminist ütopya örneklerine ise 19. yüzyılda 
rastlanmaktadır. Söz konusu dönemde kadınların seçme ve seçilme hakkı ile eğitim ve iş hayatında yer almaları için mücadele veren birinci dalga feminist hareketlerin edebiyat alanındaki yansımalarından birisi de klasik ütopya geleneğinin değişerek feminist bakış açısı kazanması olmuştur.

Kadın yazarlar özellikle toplumsal cinsiyet ilişkilerine yaklaşımlarındaki belirgin farklılıklarıyla ataerkil düzeni çözümlerken var olanı sorgulayan, verili olanı değişmez olarak kabul etmeyen yeni bir ütopya tarzı ortaya koymuş ve feminist bir duruşla yazılan bu ütopyalarda yeni bir düşünce sistemi, yeni bir dünya, yeni bir dil yaratmaya çalışmışlardır. (Sümer, 2017, s. 410)

Feminist ütopya geleneğini etkileyen önemli isimlerden biri Charlotte Perkins Gilman'dır. Yazarın 1915 yılında yazdığı Kadınlar Ülkesi romanında erkeklerin yer almadığı anaerkil bir toplumsal düzen konu edilmektedir. Kitapta üç erkeğin, tamamen kadınlardan oluşan bir ülkeye yaptığı yolculuğun ardından yaşananlar, erkek karakterin bakış açısıyla anlatılmaktadır. Kadınları, korunması ya da fethedilmesi gereken varlıklar olarak gören erkek karakterler, zaman geçtikçe bu yeni ülkedeki kadınların, kendi zihinlerindeki cinsiyetçi önyargıların tam tersine, zeki, güçlü, bilgili, becerikli ve korkusuz olduklarını keşfeder. Yazarın, kadınlardan oluşan bir dünyanın daha barışçıl ve adil olacağına dair inancı, romanın temel argümanlarından birini oluşturmaktadır. Bununla birlikte feminist ütopyaların, kadının erkekten üstün görülmesine yönelik bir anlayıșa sahip olduğu düşünülmemelidir.

Feminist ütopyalar, kadın/erkek düalizmini ve bunun yansıması olarak gelişen doğa/kültür, ruh/akıl gibi ikilikleri reddederek, cinsiyetler arasında iş birliğini, bütünleşmeyi ve böylece dengeyi yücelten anlatılar olarak kabul edilmektedir. Bu çerçevede çoğu feminist ütopyada her iki cinsiyetin özelliklerini taşıyan androjen varlıklarla karşılaşılmaktadır. Toplumsal cinsiyet anlayışından kaynaklanan bölümlenmeyi eleștiren bu anlatılardaki androjenlik hem fiziksel hem de semboliktir (Ylldırmaz, 2005, s. 128). Androjen temasını işleyen feminist ütopyalardan biri olarak Ursula K. Le Guin'in 1969 yılında yayınlanan romanı Karanlığın Sol Eli'ni örnek vermek mümkündür. Yılın belli zamanlarını kadın, belli zamanlarını ise erkek olarak geçiren insanların yaşadığı bir gezegeni anlatan roman, bir cinsiyetin diğerinden üstün olduğu görüşüne karşı çıkan, kadın ve erkeği toplumsal hayatta eşit haklara sahip, birbirini tamamlayan bireyler olarak kabul eden feminist ütopya anlayışını yansıtmaktadır.

Feminist ütopyalar, cinsiyet eşitsizliğinin kaynağı olarak gördüğü ataerkil ideolojiyi eleștirerek, kadın ve erkek arasındaki uyuma ve dengeye dayalı, eşitliğe, özgürlüklere ve adalete önem veren alternatif toplumsal düzenler önermektedir. Bu açıdan bakıldığında, her ütopyanın kendi içinde distopya potansiyeli taşıdığı görüşünün aksine, feminist ütopyaları eril distopyalar olarak yorumlamak olanaklı değildir.

Bahsedildiği üzere distopyalar, kadın ya da erkek ayrımı yapmaksızın toplumdaki tüm bireylerin baskı altında tutulduğu ve özgürlüklerinin ellerinden alındığı bir dünya tasvir etmektedir. Bununla birlikte -tıpkı ütopik eserlerde olduğu gibi- distopik kurguların çoğunluğu erkek yazarlar tarafından yazılmıştır ve dolayısıyla da bakış açısı erildir. Bu eserlerdeki kadınların, cinsiyetsiz otomatlar ya da rejimin cinsellik kurallarına meydan okuyan ve ana karakteri baştan çıkaran asiler olarak konumlandırıldığı görülmektedir (Atwood, 2004, s. 516). Kadın yazarların kaleme aldığı feminist distopyalarda ise, kadının baskı ve kontrol altına alınarak, bireyselliğinin ortadan kaldırıldığı erkek egemen totaliter bir düzen anlatılmaktadır. Feminist distopyaların odak noktasında kadın yer alır ve öykü, kadın ya da kadınların bakış açısından ilerler.

Katharine Burdekin tarafından yazılan ve 1937 yılında yayınlanan Swastika Geceleri feminist distopya geleneğini başlatan eser olarak kabul edilmektedir. Burdekin yarattığı kurgusal dünyada, Hitler yönetimindeki Nazi Almanya'sının kadınlara yönelik baskıcı politikalarından yola çıkmıştır. Romanda, Nazi hegemonyası tarafından değersiz ve aşağılık konuma yerleștirilmiş olan kadınların tek işlevi üstün Alman ırkının devam etmesi için çocuk doğurmaktır. Adeta damızlık hayvanlar gibi muamele gören kadınların toplumsal hayattan tamamen silinerek, her bakımdan güçsüzleştirilmesi benliklerini kaybetmelerine yol açmıştır. Swastika Geceleri'nin de örneklediği üzere, feminist distopyalar, ataerkil düzenin her alanda egemen olduğu bir dünyayı konu almaktadır. Siyasal, ekonomik ve toplumsal hayatın erkek tarafından düzenlendiği ve kontrol edildiği, kadının sorgusuz sualsiz itaat etmek zorunda kaldığı bir sistem söz konusudur. Bireyselliğini ve özgürlüğünü kaybettiği böyle bir düzende kadının işlevi sadece çocuk doğurmaya indirgenmiștir. Damızlık Kızın Öyküsü'ndeki ana karakterin söylediği gibi, kadınlar "iki bacaklı rahimler" den başka bir şey değildir (Atwood, 2019, s. 183). Çocuk dünyaya getirmek, kadının biyolojik kaderi olarak dayatılmaktadır. Dolayısıyla böyle bir düzende kadınlara kendi vücutları üzerinde söz sahibi olma hakkı verilmez.

Feminist distopyaları kaleme alan yazarların öncelikli amacının, ataerkil düzenin kadınlar için oluşturduğu tehdide dikkat çekmek olduğunu söylemek mümkündür. Bu türdeki eserler tasvir ettikleri dünya 
aracılığıyla toplumsal cinsiyete dayalı ayrımcılığa karşı çıkmakta ve kadınların maruz kaldığı her türlü şiddeti, tacizi, tecavüzü ve eşitsizliği eleștirmektedir. Bu çalışmanın konusunu oluşturan Damızlık Kızın Öyküsü televizyon dizisi, feminist distopyaların vurguladığı konuları gösterirken bir taraftan karanlık ve kimi zaman izlemesi zorlaşan bir dünya sunmakta, diğer taraftan ise böyle bir dünya için bile değişim ümidi olabileceğini hatırlatmaktadır.

\section{Damızlık Kızın Öyküsü}

Margaret Atwood'un 1985'te yayınlanan Damızlık Kızın Öyküsü romanı, aynı isimle 1990 yılında sinemaya, 2017 yılında ise televizyon dizisine uyarlanmıștır. İlk sezonu romandaki olay örgüsü ile benzer olan dizi yakın gelecekte, ABD'de geçmektedir. Nedeni hakkında fazla ipucu verilmeyen bir çevre felaketinden sonra kısırlık yaygınlaşmış ve bu nedenle nüfus giderek azalmaya başlamıștır. Kadınların pek azı hamile kalabilmekte, dünyaya gelen bebeklerin de ancak bește biri sağlıklı doğmaktadır. Kimin yaptığı sözde belli olmayan terör eylemlerinin iyice korkuya yol açtığı bu karışık ortamda, kendilerine 'Yakup'un Oğulları' diyen bir grup erkek, liberal demokrasiyi diktatörlüğe dönüştüren bir darbe gerçekleştirir. Böylece teokrasiye dayalı, erkek egemen, muhafazakâr bir yapı üzerine temellenen Gilead Cumhuriyeti kurulur. Yeni rejimin ilk faaliyetlerinden biri kadınların çalışma hayatından uzaklaştırılması, banka hesaplarına el konarak ekonomik özgürlüklerinin ellerinden alınması olur. Sonrasında ise, doğurganlık işlevine sahip kadınlar tespit edilir ve damızlık kız olarak yetiştirilmek üzere Kızıl Merkez'e gönderilir. Bu kadınların çocukları da yüksek rütbeli komutanların ailelerine verilmek üzere devlet tarafından alıkonur.

Ana karakter June (Offred), damızlık kız olarak komutan ve eşine tahsis edilmiştir. Dizi, June'un geçmiş hayatında eşi Luke, kızı Hannah, en yakın arkadaşı Moira ve kimi zaman da annesiyle ilgili anılarını hatırladığı geriye dönüşler ve Gilead'da, komutan Fred ve eşi Serena Joy'la yaşadıkları, diğer damızlıklarla olan arkadaşlığı ve komutanın şoförü Nick'le arasında gelişen duygusal ilişkiyi konu alarak ilerlemektedir. Dizinin ilk sezonu Atwood'un romanına sadık kalınarak uyarlanmıştır, ancak ikinci ve üçüncü sezonda yer alan olaylar kitaptan bağımsız olarak devam etmektedir.

Çalışmanın bu bölümünde, kısa özeti anlatılan Damızlık Kızın Öyküsü dizisinin yayınlanmış olan üç sezonu üzerinden Gilead toplumundaki eril iktidarın tahakküm araçları ve buna karşılık olarak bu tahakküme maruz kalan kadınların direniş yöntemleri incelenecektir.

\subsection{Gilead'ın Tahakküm Araçları}

Tarih boyunca karşılaşılan totaliter rejimlerin, sadece siyasi ve ekonomik alanda değil eğitim, aile, cinsellik ve diğer gündelik hayat rutinleri ile ilgili katı düzenlemeler ve sınırlamalar getirdiği bilinmektedir. ABD'de darbe ile iktidarı ele geçiren Gilead yönetimi de kişisel hak ve özgürlükleri yok sayan benzer uygulamalara sahip distopik bir düzen kurmuştur. Margaret Atwood Damızlık Kızın Öyküsü'ndeki evreni kurarken "İnsanların bir zamanlar bir yerlerde yapmış olmadıkları ya da yapmak için gerekli araçlara zaten sahip olmadıkları hiçbir şeye yer vermediğini" belirtmektedir $(2014$, s. 99). Yazarın bu yaklaşımı romandaki ve dizideki distopik tasarımı hayali bir kurgu olmaktan çıkararak, tarihte karşılığı olan gerçeklere yaklaştırmıştır.

Gilead, kadınların elinden ekonomik özgürlüğünü almış, bilgiye erişmesini ve bilgiyi yaymasını yasaklamış, kendi bedeni üzerindeki kontrolünü ortadan kaldırmıştır. Erkek egemen yönetim anlayışının benimsendiği Gilead'ın baskı araçları ağırlıklı olarak kadınlar üzerinde etkili olmasına rağmen, aslında erkeklerin de böylesi bir totaliter rejimde ne kadar özgür olduğuna ya da olabileceğine dikkat çekmek gerekmektedir. Komutanlar dışında kalan erkek karakterler için de istediklerini yapmakta serbest oldukları bir yaşam alanından bahsetmek mümkün görünmemektedir. Dizinin uyarlandığı kitapta komutanın söylediği "Daha iyi asla herkes için daha iyi demek değildir. Kimileri için daha kötü demektir, her zaman" sözleri söz konusu durumu örnekler niteliktedir (Atwood, 2019, s. 272). Bu doğrultuda, yönetici sınıfı oluşturan komutanlar ve diğer üst düzey görevliler için eril ütopya ülkesi olarak düşünülebilecek Gilead'daki tahakküm araçlarına değinmek önemlidir. Söz konusu baskı araçları olarak; referansı din olan kutsal metinler, damızlık kızların yeniden isimlendirilmesi ya da Gilead'daki tüm kadınların işlevlerine göre sınıflandırılarak toplumdaki statülerine işaret eden belirli renk ve modelde kıyafet giymeye zorlanmaları gibi benliği silmeye yönelik uygulamalar, eril ideolojiyi destekleyen tören ve seremoniler ile gözetim mekanizmaları ele alınacaktır.

Teokratik bir yönetim biçimine sahip olan Gilead'da dinin, yasalar ve diğer hukuk kuralları ile eșdeğer gücü bulunmaktadır. Gilead, çocuk sahibi olamayan yüksek mevkilerdeki ailelere damızlık kız tahsis edilmesine dayanan uygulamalarını, Eski Ahit'te geçen bir pasaja dayandırmıştır. Romanın başında alıntılanan söz konusu metinde çocuk sahibi olamayan Rahel eşi Yakup'a "Bana çocuk ver yoksa öleceğim" demekte ve bu duruma çözüm olarak cariyesi Bilha'yı Yakup'a sunmaktadır; “Onunla yat, benim için çocuk doğursun, ben 
de aile kurayım" (Atwood, 2019, s. 11). Bu anlayışa göre damızlık kızlar çocuk doğurarak, sadece ülkeye değil Tanrı'ya da hizmet etmiş olmaktadır. Geçmiş çağlardan itibaren toplum düzenini yönlendiren bir araç olarak kullanılan dinin, eril sistem lehine yorumlanma eğiliminde olduğunu gözlemlemek olanaklıdır. "Tektanrılı dinler, kadınların doğasına, statüsüne ve rolüne ilişkin normları vazederken, içine doğdukları ve karşılığında meşrulaştırıp pekiştirdikleri ataerkil sınıflı toplumlarda var olan değerleri temel almışlardır" (Berktay, 2014, s. 26). Böylece dini söylemler eril ideoloji için meşrulaştırma işlevi üstlenmiștir.

Teun Van Dijk iktidarın kurulması ve yeniden üretilmesi için söylemin önemine dikkat çekmektedir.

İktidarın uygulanımı için hayati olan nokta, bilgi ve inançların ustaca yönlendirilmesi, inançların önceden formülleștirilmesi ya da karşı-ideolojilerin sansür edilmesi yoluyla toplumsal bilişlerin oluşumu üzerinde denetim kurmaktır. Bu tasarımlar toplumsal iktidar ile söylemin üretimi, anlaşılması ve iktidarın harekete geçirilmesinde söylemin toplumsal işlevleri arasındaki temel bilişsel bağlantıyı oluşturur. (1994, s. 378)

Sorgulanamaz özellikleri ile dini söylemler, Van Dijk'ın ișaret ettiği üzere, Gilead iktidarının gücünü besleyen ve bu iktidarı yeniden üreten en önemli dinamolardan biri haline gelmiștir. Kadınlar üzerinde uygulanan insanlık dışı politikaların büyük kısmı gücünü ve meşruiyetini kutsal metinlerden almaktadır. Dini buyrukların sorgulanamaz dogmalar olarak dayatıldığı bu düzende, dini metinler rejimin çıkarları doğrultusunda yanlış yorumlanmakta ve amacından saptırılmaktadır. Söz konusu metinlerin ana kaynağı olan İncil sadece komutanların erişebildiği ve kadınların okumasına izin verilmeyen kitaplar arasında yer aldığından, söz konusu buyrukların gerçekliğini kontrol etmek mümkün değildir. Bununla birlikte, muhafazakâr Gilead rejiminde kadınlar, iffetlerini korumaları ve ahlaka uygun davranmaları yönünde katı bir denetim altında tutulurken, diğer taraftan her ay tecavüze uğramalarının çelişkili olduğu vurgulanmalıdır. Bu nedenle Gilead'da eril iktidarın otoriter ve baskıcı politikalarını meşrulaştırmak için dini alet ettiği ortaya çıkmaktadır.

Bir diğer tahakküm stratejisi olarak Gilead toplumunda damızlık kızların kendi isimlerini kullanmalarına izin verilmediği görülmektedir. İngilizce'de aidiyet belirten of ekinin damızlık olarak verildikleri evin erkeğinin ismine eklenmesiyle Offred (Fredinki) veya Ofglen (Gleninki) şeklinde anılırlar. Damızlık kız başka bir eve atandığı zaman, ismi tekrar değişmekte ve yeni evin komutanının ismini almaktadır. Bu stratejinin amacı, kadını kendi öznelliğini belirleyen isminden mahrum bırakarak kimliksizleștirmektir. Damızlık kızlar, geçmiş hayatlarına dair ellerinde kalan tek şey olan isimlerini de yitirerek, kimliklerinden ve geçmişlerinden uzaklaştırılmaktadır. Dizide ana karakterin adı June olarak geçmekle birlikte, romanda gerçek ismi belirtilmemektedir. Margaret Atwood bu durumun nedenini tarih boyunca adları değișen ya da kaybolan insanları örnek vererek açıklamaktadır. Yazar ayrıca, kahramana verilen Offred isminin İngilizce offered gibi bir olasılığı da içerdiğini ve dini bir adak veya kurbanlık olarak sunulan bir anlama işaret ettiğini belirtir (2019, s. 17). Dünyaya çocuk getirmekten başka işlevi olmayan varlıklara indirgenen damızlıkların isimsizleștirilmesi; bir yandan kadını erkeğin kullanımına tahsis edilmiş biyolojik bir nesne konumuna yerleştirirken, diğer yandan komutanın ismiyle anılır olması kadının erkeğe olan tabiiyetini vurgulamaktadır.

Gilead'ın toplumsal düzenlemeleri büyük oranda kadınların sınıflandırılmasına dayanmaktadır. Söz konusu sınıflandırma, Hıristiyan düşünür Augustinus'un, Tanrı Devleti isimli eserinde yaptığı kadına yönelik ayrımı hatırlatmaktadır. Buna göre Augustinus kadını üç şekilde ele almaktadır; baştan çıkarıcı olarak kadın, şeytanın kötü planlarının aracıdır; eş olarak kadın, ailenin düzenini korumakla görevli kocanın aracıdır ve anne olarak da Tanrı'nın yaratıcllı̆̆ıın aracıdır. Hangi amaca hizmet ettiğine bağlı olarak, kadın ya lanetlenir ya da kutsanır (Agonito, 1977, s. 74). Kadınların Augustinus'unkine benzer ancak daha detaylı sınıflandırılması Damızlık Kızın Öyküsü'nde de karşımıza çıkmaktadır. Gilead toplumunda yedi tip kadın bulunmaktadır. Bunlar; doğurganlığa sahip damızlıklar, damızlıkları disipline ve kontrol etmekle sorumlu Teyzeler, doğurganlık işlevi olmadığı için ev işleriyle görevlendirilen Martha'lar, düşük rütbeli (gardiyan) veya rütbesiz (econopeople) erkeklerle evli ekono-kadınlar (econowives), ev içi alana hapsedilmiş komutan kocalarına bağımlı Eşler, komutanların cinsel fantezilerini gerçekleștirmeleri için özel mekânlarda çalıştırılan Jezebeller ve son olarak suç işlemiş ve bu nedenle zehirli atıkları temizleme yöntemiyle yavaş ve acılı bir ölüm için kolonilere gönderilen, doğurgan olmayan gayrikadınlardır (unwoman). Gilead kadınlarının bu şekilde sınıflandırılması Leigh K. Kolb’a göre köle sınıfının yeniden tesis edilmesidir (2019, s. 45). Köle sınıfı içindeki iş bölümü ise, erkeğin fiziksel, cinsel ve duygusal ihtiyaçlarının en iyi şekilde karşılanmasına yönelik olarak düzenlenmiştir. Toplum içindeki statülerini eşleri aracılığıyla sağlamlaştıran komutanların gündelik işleri Martha'lar tarafından halledilmekte, cinsel fantezileri için Jezebeller devreye girmekte ve soylarının devamı için de damızlık kızlar imdada yetişmektedir. 
Kadınların hangi sınıfa ait olduğu, giydikleri kıyafetlerin rengi ve biçimi ile daha da fazla vurgulanmaktadır. Damızlık kızlar kırmızı, eşler mavi, Marthalar yeşil, teyzeler kahverengi ve ekono-kadınlar gri renkli elbiseler giymek zorundadır. Giysi konusu tarih boyunca genellikle kadın etrafında şekillenmiştir ve günümüzde de hala kadınların nasıl giyinmesi gerektiğini dikte etmek isteyen zihniyetler varlığını sürdürmektedir. Atwood, damızlık kızın elbisesinin tasarımının, belli bir dini baz almadığını, çocukluğunda satılan lavabo temizleyicilerinin üzerindeki 'Yaşlı Hollandalı Temizlikçi' figüründen ilham aldığını söylemekle birlikte, yüzü gizlemeye yarayan şapka ve bonelerin kullanıldığı Viktoryen Dönem'e de işaret etmektedir (2014, s. 100). Damızlıkların dışarı çıkarken takmak zorunda olduğu ve yan yana yürüyüp önemsiz konularda sohbet ederken bile birbirinin yüzüne bakmalarını olanaksız hale getiren başlıklar, kadınları 'korumaya' yönelik olduğu iddiası taşımaktadır. Ancak bu iddianın arkasındaki asıl amaç, kadınların tam anlamıyla görmesini ve aynı zamanda görülmesini önlemektir. Böylece iletişim kurmak, çevreyi algılamak ve anlamak mümkün olduğu kadar zorlaştırılmaktadır.

Herhangi bir dinle ilgisi olsun ya da olmasın insanlara belirli tipte kıyafetler giymeyi dayatma politikası, distopyalarda ve ütopyalarda tahakküm aracı olarak sıklıkla yer almaktadır. Thomas More'un Ütopya'sında olduğu gibi vatandaşlarının tek renk ve biçimde kıyafet giymek zorunda olduğu bir düzen söz konusudur. Eril ütopya ülkesi Gilead da kadının bireyselliğini silerek anonim hale getirmek amacıyla önce isimlerini ellerinden almakta ve sonra tek tip kıyafetler içine hapsederek kimliksizlik duygusu oluşturmaktadır. Philip Zimbardo, bașkaları tarafından özel bir birey değil, sadece sistem tarafından işlenen birbirinden farksız 'diğer'leri gibi davranıldığında ya da varlığı önemsenmediğinde kişinin kendisini kimliksizlik hissedeceğini vurgular (2007, s. 473). Böylece bireylerin benliklerini ortaya koyabilecekleri kişisel özellikleri baskılanarak, uyum ve itaat sağlanmaktadır. Öte yandan kadınların bu şekilde kimliksizleştirilmesinin bir diğer işlevi, erkeklerin kadın üzerinde egemenlik ve kontrol kurma anlayışını harekete geçirmesidir. Çünkü kimliksizleştirme, insandışılaştırma sürecinin parçasıdır ve insandışılaştırılan bireylerin hakları kolaylıkla göz ardı edilebilir.

Gilead rejiminde tören ve seremonilerin de önemli bir yeri bulunmaktadır. Kalabalıklar eşliğinde gerçekleştirilen evlilik ve özellikle doğum seremonileri, rejimin aile ve üremeye dair dayatmasını vurgulamaktadır. Damızlık kızların, 'atandıkları' evde, zamanlaması yumurtlama dönemine denk gelecek şekilde ayarlanan ve 'seremoni' olarak adlandırılan cinsel birleşme ise, önce ev halkının tamamının katılımıyla ve dualarla başlamakta, sonrasında ise eşin gözü önünde (hatta kucağında) komutan ve damızlık kız arasında gerçekleşmektedir. Dokunmanın, zevk almanın ya da herhangi bir duygunun yasak olduğu bu birleşme, açık bir tecavüz olduğu halde rejim tarafından 'kutsal bir görev' olarak nitelendirilmektedir.

Gilead'daki törenler ise genellikle cezalandırmaya yöneliktir ve izleyiciler önünde gerçekleştirilir. Herhangi bir iktidarın varlığını sürdürmesi, gücünü pekiştirmesi için suça ve suçlulara ihtiyacı olduğu, dolayısıyla suçun iktidarın yararlandığı bir unsur haline geldiği göz önüne alındığında, yasa koyucunun suça karşı oluşturduğu ceza sayesinde gücünü gösterdiği, kendisine duyulan güveni veya korkuyu pekiştirdiği ve bu güveni/korkuyu sürekli olarak yeniden inşa ettiği görülmektedir. Emek Çaylı Rahte'nin de işaret ettiği üzere korku yaratmak ve tahakküm kurmak patriyarkanın varlığını sürdürmesi için eldeki en önemli kozdur. "Korkunun olmadığı yerde tahakkümün araçları işlevsizleşir, tesisi güçleşir" (2018, s. 26).

Dizide anlatılan evrende, söz konusu korkuyu yaratmak için kullanılan yöntemlerden biri de topluluk önünde yapılan infazlardır. Cezalandırmanın fiziksel acı çektirmeye ve seyirlik olmaya dayalı olması Aydınlanma Dönemi'ne kadar varlığını sürdüren en eski uygulamalardan biridir. Michel Foucault, Hapishanenin Doğuşu (1975/2006) adlı kitabında idam gibi ölüm cezaları ile çeşitli uzuvların koparılması, kırbaçlama, dağlama ve damgalama gibi işkence yöntemlerinin, fiziksel acı çektirmeye dayanan cezalar olarak geniş kitleler önünde gerçekleştirildiğine dikkat çekmiştir (s. 40-41). Bedeni en şiddetli şekilde cezalandırmaya yönelik bu tarz gösteriler, ileride gerçekleşme olasılığı olan benzer suç eylemleri için caydırıcı ve ibret olma niteliği taşımaktadır. Gilead Rejimi de idam cezalarını kalabalık izleyicilerin önünde ve hatta kimi zaman damızlık kızların da katıldığı toplu bir törende gerçekleştirmektedir. Kadınların infaz eylemine cezalandırıcı olarak katıldığı bu törende, damızlıklar çember oluşturarak suçluyu taşlamakta ya da çıplak elleriyle suçluya saldırmaktadır. Bu durum romanda İngilizce participation (katılım) ve execution (infaz) sözcüklerinin birleşimi olarak particicution şeklinde adlandırılmaktadır. Katı biçimde denetlenen damızlık kızların, bir erkeğe öldüresiye saldırıp içindeki bastırılmış öfke ve isyan duygularını bu şekilde boşaltması, sistem tarafından emniyet supabı işlevi görmektedir. June'un bu durum ile ilgili yorumu "Hep beraber yapılınca suç kimsenin üzerine kalmaz"dır (Atwood, 2019, s. 354) ve böylece kadınların 'toplu cinayet' eylemi meşrulaştırılmış olmaktadır. İnfazın ardından kentin belli noktalarında isyancıların cesetlerinin asılı vaziyette sergilenmesi de yoldan geçerken ölü bedenleri gören herkese sisteme karşı çıkmanın sonuçlarını hatırlatmaktadır. 
Bütün totaliter rejimlerde görüldüğü üzere, vatandaşları baskı ve kontrol altında tutmak için gözetim mekanizmalarını kullanmak Gilead Cumhuriyeti'nin de başvurduğu en etkili tahakküm yöntemlerinden bir diğeridir. İktidar bunun için öncelikle kamusal ve özel alanı tamamen kontrolü altında tutmaktadır. Toplumsal mekânların, toplumsal cinsiyet kurallarıyla düzenlendiğine dikkat çeken Serpil Çakır, kadınların hane dışındaki mekânlara girme ve bu mekânları kullanma koşullarının, erkek egemen bir kurum olan devlet tarafından belirlendiğini belirtmektedir (2009, s. 78). Yazara göre kadınların dış mekânlara girişine, genellikle denetimin çeşitli biçimleri aracılık etmiş; dış mekâna nereden, ne zaman ve hangi şekille-giysiylegirileceği kurala tabi kılınmıștır. Çakır'ın tespitini destekler șekilde Gilead'da Damızlıkların sadece mutfak alışverişi yapmak üzere dışarı çıkmalarının serbest bırakıldığı görülmektedir. Bu kısa geziyi tek başlarına değil, ikili gruplar halinde yanlarında bir başka damızlıkla birlikte yapmaları mecbur tutulmuştur. Gezileri sırasında Damızlıkların birbirlerine dini temennilerde bulunması önemlidir ancak taze sebze ve meyveler dışında bir konu hakkında sohbet etmeleri hoş karşılanmamaktadır. Bu tarz bir durumda kendilerini sürekli izleyen silahlı görevliler tarafından hemen uyarılırlar. Böylece güvene dayalı yakın bir ilişki kurmalarının ve aralarında muhalif söylem geliştirmelerinin önüne geçmek amaçlanır.

Gilead'da ataerki sadece kamusal alanda değil, özel alanda da sınırsız hâkimiyete sahiptir. Gilead toplumundaki kadın kategorileri arasında hiyerarşik açıdan en üst konumlardan birinde bulunan eşlerin bile düzenlenmesinden sorumlu olduğu evde tam denetime ve özgürlüğe sahip olduğunu söylemek olanaklı değildir. Sözgelimi eșlerin, komutanın evdeki çalışma odasına girmesi yasaktır. Kitaplar, dergiler, yazı yazma gereçleri gibi kadınlara yasak olan her türlü eşya ile dolu olan bu odayı, erkeğin toplumsal hayat üzerindeki kontrolünün ve hâkimiyet alanının mikro boyuttaki versiyonu şeklinde okumak gerekmektedir.

James C. Scott, Tahakküm ve Direniş Sanatları isimli kitabında, hâkim grupların, tabi sınıfı disiplin altına almak, egemen söylemle çelişen ya da bu söylemi değiştiren, potansiyel olarak yıkıcı olabilecek her türlü söylemi izlemek için gözetim modeline ihtiyaç duyduğunu belirtmektedir (2018, s. 198-199). Yazara göre gözetim, "Gizli senaryoların doğabileceği tüm küçük, özerk toplumsal alanları ve toplumsal bağları önlemek için" alınan önlemlerden biridir. Hatırlanacağı üzere, distopik 1984 romanında da Parti'nin en önemli baskı aracı, vatandaşları kamusal ve özel alanda, günün her saati izleyen Büyük Birader isimli gözetim mekanizmasının varlığıdır. İnsanların gözlendiğini bilmesi, her türlü aykırı ve karşıt eylemi en başından ortadan kaldırmaktadır.

Gilead rejiminin de 1984'teki kadar uç boyutta olmasa da gözetimin baskı kurucu gücünden faydalandığı görülmektedir. Bu doğrultuda Gözler (Eyes) adı verilen gizli polisler, sistem karşıtlarını tespit etmek ve her türlü şüpheli aktiviteyi izlemek için çalışmaktadır. Kimliği gizli bu kişiler sadece damızlıkları değil, statüsü fark etmeksizin bütün kadınları ve hatta komutanları bile gözetim altında tutmaktadır. Olușturulan korku ve güvensizlik ortamı kendi başına kontrol ve tahakküm aracı olarak karşımıza çıkmakta ve Jeremy Bentham tarafından tasarlanan Panoptikon isimli hapishane modelini hatırlatmaktadır. Model, mahkûmları rahatça izleyecek şekilde konumlandırılmış ancak içi görülmediği için mahkûmların kendilerini izleyen birisinin olup olmadı̆̆ından emin olamadıkları bir gözetleme kulesine dayanmaktadır. Foucault, görülmeden gözetim altında tutmaya yarayan bu tahakküm aracının, iktidarın görünür ve varlığının kanıtlanamaz olması ilkesini yansıttı̆̆ını savunmaktadır (Foucault, 2006, s. 297). Buna göre gözetleme kulesi iktidarın varlığının somut bir sembolüdür. Kulenin içindeki nöbetçiye dair kesin bilgi olmamasına rağmen, 'gözetlenme' halinden şüphe duyulmaması ise varlığı kanıtlanamaz olsa dahi iktidarın mutlak gücüne işaret etmektedir. İsyana yönelik herhangi bir düşüncenin dile getirilmesini engellemek ve potansiyel direniş olasılığının önüne geçmek için Gilead'daki herkes yakından takip edilmektedir. Ancak burada asıl önemli olan Gilead'daki 'Göz'lerin sürekli olarak herkesi izliyor olması ihtimali değildir. Dikkat edilmesi gereken nokta, bu ihtimalin Gilead'da baskı altında tutulan herkesi kendi kendilerinin gardiyanı haline getirerek, dışsal baskıyı içselleștirmelerine yol açmış olmasıdır.

\subsection{Direniş Olanakları}

Tarih, egemen sınıf ile tabi sınıf arasındaki gizli ya da açık çatışmaların örnekleriyle doludur. Her iktidar, kaçınılmaz olarak kendi muhalefetini yaratmaktadır. Dolayısıyla yönetenlerin tahakküm araçlarının olduğu yerde, yönetilenlerin direnişi de mevcuttur.

Erica A. Holberg, Damızlık Kızın Öyküsü'ndeki tahakkümün, bireyin benlik algısını silip onu başkalarının kullanımı için bir 'şey'e dönüştürme yoluyla işlediğini belirtir (2019, s. 132). Yazara göre benlik algısını silmek için bireyin özsaygısına yönelik iki tür sistemli saldırı uygulanmaktadır: korku ve utanç. Acıdan ve kendisi ya da sevdiklerini tehdit eden ölümden kaçınmak için kişinin en katlanılamaz görülen eziyetlere bile boyun eğmesinin ve aşağılayıcı durumlara ses çıkaramamasının kökeninde korku yatmaktadır. Korkunun gölgesinde kendisini zayıf, kırılgan ve yalnız hisseden birey zamanla utanç duygusuna yenilir ve özsaygısını kaybeder. 
Damızlık Kızın Öyküsü'nde ana karakter June da başlangıçta benzer bir haysiyet kaybı içinde, herhangi bir direniş çabası ya da düşüncesinden uzak görünmektedir. Acı çektiği anlaşılmakla birlikte sessiz bir itaat ve kabulleniş sergiler. Kaldığı odada, kendisinden önceki damızlık kızın duvara kazıdığı Latince cümleyi fark etmesi, June için ilk kırılma anını oluşturur. Duvara Nolite te bastardes carborundorum sözleri kazınmıştır. Cümlenin 'Piçlerin seni ezmesine izin verme!' anlamına geldiğini öğrenen June, bunu yazan damızlık kızın kendisini astığını bilmektedir. Yaşadığı koşulların ağırlığına dayanamayan isimsiz damızlık kız intiharı seçmiş, kendisinden sonra gelecek yeni damızlık için de intihar notu bırakmıştır. Direnmesini, mücadele etmesini ve aynı kaderi yaşamamasını örtük biçimde öğütlemektedir. Böylece, o zamana kadar sessiz bir kabullenme ya da en basitinden sadece hayatta kalma çabası içindeki June için bu sözler direniş umudunun varlığına ișaret eder. Umudun yeniden tesis edilmesi, özsaygının yeniden kazanılması için bașlangıçtır (Holberg, 2019, s. 137) ve özsaygı da direnişin temelinde yer alır. Dolayısıyla June'un odasına kazınmış olan cümleyi, olay örgüsü ilerledikçe June'un liderliğini üstleneceği, kadın dayanışması üzerine kurulu direniş hareketinin ateşleyicisi olarak yorumlamak mümkündür. Damızlık kızların arasında başlayan ve Marthaların katılımıyla zaman içinde örgütlü hale dönüşecek olan bu direniş eylemleri; June'un hikâye anlatıcılığı ve gelecek nesiller için tanıklık çabası, iktidarın güç gösterilerine yönelik başkaldırılar, eril kontrol altındaki mekânın tahribatı ve kadın dayanışmasını örnekleyen Yeraltı Kadın Yolu ve Mayday Örgütü çerçevesinde incelenecektir.

Toplumsal iktidar biçimlerinin çoğu zaman dolaylı bir şekilde ve zihinsel denetim yoluyla işlediğini belirten Van Dijk'a göre zihinsel denetim, ikna ya da söylemsel iletişim biçimleri aracılığıyla uygulanmaktadır. "Toplumsal iktidarın uygulanması ve korunması ideolojik bir çerçeveyi gerektirir. Toplumsal olarak müşterek bir grubun ve üyelerinin çıkarla ilgili temel bilişlerinden oluşan bu çerçeve esasen iletişim ve söylem yoluyla kazanılır, onaylanır ya da değiştirilir" (Van Dijk, 1994, s. 335). İktidar, söylemin içinde ve söylem aracılığıyla oluşmaktadır. Dolayısıyla söylemin üretimi ve denetimi toplumsal iktidarın önemli bir koşuludur. Bu açıdan bakıldığında, resmi tarih söyleminin çoğu zaman egemenler tarafından üretildiği gerçeğiyle karşılaşılmaktadır. Buna göre belirli sınıf, ırk, din ve cinsiyet mensuplarına ait hikâyelerin dışarıda bırakıldığı, yanlı ve eksik bir tarih yazımının söz konusu olduğu düşünülmektedir. Başka bir ifadeyle resmi tarih, egemen sınıfın söylemine dayanarak oluşturulmakta, tabi sınıfların söylemi ise genellikle ihmal edilmektedir. Bu doğrultuda tarih yazımının ideolojik olduğunu söylemek mümkündür. Bu nedenle tarihsel olmak üzere her tür söylemi oluşturan, düşünceleri ve ideolojileri taşıyan bir araç olarak dilin kontrolü iktidar için önem kazanmaktadır. Dil üzerinde mutlak kontrol kurmaya dayalı politika yürüten totaliter rejimler, distopik eserlerde sıklıkla yer almaktadır.

Erkek egemen ideolojiye dayalı Gilead Cumhuriyeti'nde de kadının susturularak dıșarıda bırakılmasına dayanan ve dilin eril geleneğe göre biçimlenmesiyle yazılan history'nin ${ }^{3}$ en uç noktasına varmış olduğu görülmektedir. Okuması ve yazması yasaklanan, yani dili kullanma hakkı neredeyse ellerinden alınmış olan kadınların sakınmadan kurabildikleri cümleler (Tanrı meyveni kutsasın, Tanrıya şükür ve Tanrı gözetsin), eril iktidarın izin verdiği dini konularla ve kadınların üreme işlevi ile ilgilidir. Hatta komutan ve eşiyle birlikte June'un başkente yaptığı seyahatte görüldüğü üzere, Washington'da tüm damızlık kızlar, ağızlarına yerleștirilen metal halkalar vasıtasıyla konuşmaktan da mahrum bırakılmıștır.

Bu doğrultuda, Gilead'da yaşananlar hakkında June'un doldurduğu ses kasetleri ya da Kanada'ya kaçmayı başaran kadınların kaleme aldığı mektuplar, dili ele geçirmeye yönelik önemli bir mücadele olarak okunmalıdır. Gilead Cumhuriyeti yıkıldıktan yüzyıllar sonra söz konusu kayıtlar, herstory olarak tarihi belge statüsü kazanacaktır (Howells, 2006, s. 165). Tarih yazımındaki cinsiyetçiliği önleyen böyle bir girişim için ise öncelikle kadının dili ele geçirmesi gerekmektedir. Damızlık kızlar tarafından yazılan mektupların bir şekilde June’a ulaşması bu bakımdan önemlidir. Bütün mektupları tek tek okuyan June, bunları Kanada'ya kaçırmak ve böylece Gilead'daki totaliter uygulamalar hakkında dünyanın geri kalanının haberdar olmasını sağlamak ister. Mektupların internette yayınlanması, Gilead'ın dünyanın geri kalanına karşı çizmeye çalıştığı imajı büyük ölçüde sarsar ve böylece June ve diğer muhaliflerin Gilead'a karşı ilk zaferi kazanılmış olur. Dizinin üçüncü sezonu itibariyle June'un da kendi hikâyesini anlatarak ses kayıtları oluşturduğu görülmektedir. Bu çerçevede kadınların kurabileceği cümleleri sınırlayan Gilead'ın eril sisteminde kadınların kendi kelimelerini seçerek, kendi hikâyelerini anlatmaları, başka bir ifadeyle 'dili kullanmaları' önemli bir başkaldırı olarak yorumlanmalıdır. Dil üzerinde kontrole sahip olmak, kadını nesne konumundan özne konumuna taşımakta ve bu aktif pozisyon, iktidarın otoritesini sarsacak bir güç potansiyeli taşımaktadır.

\footnotetext{
${ }^{3}$ Tarihin erkekler hakkında ve erkekler tarafından yazıldığı, kadınların hikâyelerinin dışarıda bırakılarak kurgulandığı anlamına gelmektedir.
} 
Dili kullanmanın taşıdığı söz konusu güç, dizinin ikinci sezonundaki bir sahnede özellikle vurgulanmaktadır. Yaralandığı için komutanın hastanede yattığı dönemde Serena Joy ve June geçici süreliğine iş birliği yapar ve komutanın işlerini onun yerine gizlice yönetir. Uzun zaman sonra, devlet işleriyle ilgili de olsa, okuma ve yazma olanağına kavuşan iki kadının yürüttüğü bu iş birliği, hem ikili arasındaki sıkıntılı ilişkinin farklı bir yöne doğru evrilmesini sağlar hem de komutanın işlevsizliğine dikkati çeker. June'un elindeki kalemin arkasına bastığı sırada, kalemin bomba ateşleyicisini çağrıștırdığı sahne ise kaleme sembolik bir anlam yüklemektedir. Buna göre bilgiye ulaşmak ve bilgiyi üretmek devrimci bir hareket olarak yorumlanabilir ve Gilead'da kalemi olan bir kadın güç sahibidir. Kaleme benzer sembolik anlamı yükleyen bir diğer sahnede June, kendisine tecavüz etmek isteyen Komutan Winslow'u kalem saplayarak öldürmektedir. İşlevi yazı yazmakla sınırlı bir araç olan kalem ile bomba ateşleyicisi ya da bıçak arasında kurulan bu analoji, kalemi şiddetle ilişkilendirmekle birlikte asıl olarak güç ve iktidar aracı şeklinde konumlandırmaktadır.

Hatırlanacağı üzere, Gilead'da eril iktidarın baskı araçlarından biri olarak toplu cezalandırma törenleri düzenlenmektedir. Kamusal alanda gerçekleştirilen, görünür ve dışa dönük güç gösterileri ve temsilleri, iktidarın tabi olanlar üzerindeki izlenimini güçlendirmek ve sürdürmek için sahneye konulmaktadır (Scott, 2018, s. 88-91). Bu tür üstünlük performansları, otoritenin gücünün tezahürü olarak genellikle göz korkutucudur ve iktidarı pekiștirir. Bununla birlikte bu tarz gösteriler, iktidarın en kırılgan olabileceği anlardan biri olarak görülebilir, çünkü 'büyüklük zırhlarını' zedeleyebilecek herhangi bir çatlak, kamusal sahnede ortaya çıtığında iktidarın bırakmak istediği izlenim zarar görür.

Gilead'ın üstünlük gösterilerinden biri olan toplu ceza törenlerinden birinde damızlık kızlardan, arkadașları Janine'i taşlayarak öldürmeleri istenir. Tüm kadınlar ellerinde büyük bir taş parçası ile Janine'in etrafında toplanır ancak June, töreni yöneten teyze Lydia'ya karşı çıkar ve taşı arkadaşına atmak yerine yere bırakır. Diğer kadınlar da onun gibi yapar. Bu, damızlık kızların kolektif bir şekilde otoriteye karşı geldikleri ilk eylemdir ve sonrasında çok ağır biçimde cezalandırılmış olsalar da dayanışma ruhunun oluşması ve Janine'in hayatını kurtarmış olmaları bakımından önemli bir direniş hareketi olarak kabul edilmesi gerekmektedir. Herkesin gözü önünde yapılan güç gösterilerinde, direnişin açık ve toplu biçimde gerçekleşmesi, iktidarın otoritesine yönelik ciddi bir meydan okumadır.

Damızlık Kızın Öyküsü'ndeki bir diğer direniş biçimi, mekânın tahrip edilmesi şeklinde karşımıza çıkmaktadır. Mekânın, özellikle de sınırlayıcı niteliği ile evin, iktidar için etkili bir tahakküm aracı olduğu vurgulanmalıdır. Simone de Beauvoir kadının erkeğe tabi kılınması sürecinin arkasında, kadının kamusal alandan uzaklaştırılarak ev hayatına yönlendirilmesinin yattığını savunur (1993, s. 8-9). Yazara göre ev ve mutfak işleri kadına sabrı ve edilgenliği öğreten faaliyetlerdir. Dolayısıyla kadının ev içi alana hapsedilerek edilgenleştirilmesi Gilead'ın sistematik biçimde uyguladığı stratejilerden biridir. Görünürde evi içi alanı yönetme hakkına sahip olan eşlerin mekân üzerindeki kontrolü yanıltıcıdır ve aslında 'hanımı' oldukları ev, kadın için hapishaneden farksızdır. Komutan Fred'in eşi Serena Joy da geçirdiği dönüşüm içerisinde bunun farkına varır. Kendisi, eşiyle birlikte Gilead Cumhuriyeti'nin mimarları arasında yer almaktadır. Ancak kurulmasına yardım ettiği düzen, onun da hak ve özgürlüklerini büyük oranda elinden almıștır. Eskiden kalabalıklar önünde konuşabilen, maddi özgürlüğe sahip bir kadınken, kitap okumasını, araba kullanmasını, çalışmasını yasaklayan yeni düzende ev içi alana hapsolmuştur. June'la yakınlık/düşmanlık arasında gidip gelen iliş̧kileri boyunca karakteri yavaş yavaş değişir ve Gilead'ın kendisi için de tehdit olduğunu anlamaya başlar. Serena'nın bu farkındalığı gösterdiği en kritik anlardan biri, bebeğini Gilead'dan uzaklaştırması için June'a yardım ettiği sahnedir. Komutan ve Serena'ya vermek üzere kız çocuğu dünyaya getiren June bebeğiyle birlikte kaçmayı planlamıştır. Bu planda Marthalar da organize şekilde ona yardım etmektedir. Son olarak Serena da bebeğin Gilead'dan uzakta büyümesinin daha iyi olacağını kabul ederek iş birliği yapar. June kendisi kaçamaz ama kızını göndermeyi başarır.

Serena'nın yaşadığı dönüşümün en görünür olduğu an ise June'un kendisi için dünyaya getirdiği bebekten vazgeçtikten sonra yatak odasından başlayarak evi ateșe verdiği sahnedir. Serena'nın özel alana ve aileye ait bir mekân olarak evi yakması, eșiyle birlikte kurduğu düzene karşı tepkisinin dışavurumu olarak okunmalıdır. Ancak daha önemlisi Gilead'daki totaliter düzenin mikro tahakküm alanı olarak evin alevler içindeki görüntüsü, onu adeta bir direniş fişeğine dönüştürmüştür.

Gilead'da hükümet karşıtı iki aktif oluşum bulunmaktadır. Bunlardan birincisi olan Yeraltı Kadın Yolu, Gilead'dan Kanada'ya kaçmaya çalıșanların kullanabileceği kaçıș yollarına ișaret eden bir kurtarma operasyonuna karşllık gelmektedir. June'un eşi Luke, yakın arkadaşı Moira ve sonrasında Emily bu yolu kullanarak ülke dışına çıkabilmiştir. Diğer direniş organizasyonu olan Mayday ise yarı askeri bir örgüttür. Mayday kelimesi ilk olarak damızlık kızlardan biri olan, June'un alışveriş arkadaşı Emily tarafından kullanılır, sonradan kendisinin de örgütün üyesi olduğu anlaşılır. İlk iki sezonda Mayday'in nasıl bir ağa sahip olduğu hakkında fazla bilgi verilmemekle birlikte, üçüncü sezonda Martha'lardan oluşan güçlü bir 
şebeke ortaya çıkmaktadır. Kendilerine özgü bir iletişim yöntemi ile haberleşen kadınlar, dizinin sezon finalindeki büyük kaçışta önemli rol oynamaktadır. June, Gilead'ın devamını ve kalıcılığını sağlamak için güvendiği ve bu amaçla yetiştirmeye çalıştığı çocukların, damızlık kızlar ve Marthaların yardımı ile Kanada'ya kaçmalarını organize eder. Tehlikeli ve riskli bir operasyonun, Mayday aracılığı ile başarıya ulașması direniș organizasyonunun karșılıklı dayanıșma, güven ve iş birliğine dayalı olduğuna işaret etmektedir. Bu doğrultuda Mayday'i, distopik Gilead'daki ütopya ışığı olarak görmek mümkündür. Bahsedildiği üzere her ütopyanın içinde distopya, her distopyanın içinde de ütopya bulunmaktadır. Baskıcı Gilead rejiminden kaçmak isteyenlere yardım eden, bu kişileri korumaya çalışan, direnen bir topluluğun varlığı kurtuluş umudu anlamına gelmektedir.

\section{Sonuc}

Distopik eserler, yazıldığı dönemde dünyada yaşanmakta olan ekonomik, politik, kültürel, coğrafik ve teknolojik gelişmeler hakkında farkındalık yaratma, eleştirel bir bakış oluşturma ve bu gelişmelerin yol açabileceği olumsuzluklara dikkat çekme amacı taşımaktadır. Distopyaları, bardağın boş tarafına işaret eden felaket habercileri olarak görmek yerine, olası tehlikeler hakkındaki uyarılar şeklinde düşünmek daha doğru bir yaklaşım olacaktır.

Feminist distopyalar ise, ataerkil politikaların egemenliğindeki düzende kadınların maruz kaldığı eşitsiz ve haksız uygulamaları konu almaktadır. Günümüzde kadınların hala siyasi, sosyal ve kültürel alanda ayrımcılığa maruz kaldığı, bazı ülkelerde araba kullanmasının, tek başına seyahat etmesinin, stadyumda maç izlemesinin dahi yasak olduğu göz önüne alındığında, feminist distopyalar hayali kurgular değil, gerçeklerden yola çıkan anlatılar olarak önem kazanmaktadır. Bu bakımdan feminist ütopyaların hayal gücüne daha çok başvurduğunu söylemek mümkündür. Çünkü feminist distopyalar ne yazık ki kadınların cadı avı adı altında yakıldığı, toplu halde tecavüze uğradığı, köleleștirildiği, sünnet edildiği, sosyal ve siyasal haklarından mahrum edildiği bir tarihsel gerçeklikten beslenmektedir.

Her distopik anlatıda olduğu üzere feminist distopyalar da bugünün dünyasını doğru anlayabilmenin ve eleştirebilmenin yöntemlerinden biridir. Bu doğrultuda feminist distopyaları bir uyarı ve aynı zamanda öngörü şeklinde düşünmek gerekmektedir. Dolayısıyla kadınların bilinçlenmesi ve kendisini ikincil konuma yerleștiren ataerkil sistemle mücadele etmesi için farkındalık kazandırmak feminist distopyalar için önemlidir.

Feminist distopya geleneğine ait pek çok önemli roman bulunmakla birlikte, bu romanlardan televizyona ya da sinemaya yapılan uyarlamaların görece daha az olduğunu söylemek mümkündür. Dolayısıyla feminist distopya üzerine ve Damızlık Kızın Öyküsü özelinde yapılan çalışmaların ağırlıklı olarak edebiyat alanında olduğu görülmektedir. Bu çalışma ise Damızlık Kızın Öyküsü dizisini, uyarlandığı aynı isimli romandan bağımsız olarak ele almaktadır. Dizinin görsel dili, romandan farklı ilerleyen olay örgüsü ve kurgusal evrenindeki tahakküm uygulamaları ile direniş olanakları çerçevesinde yapılan analizin, feminist distopya geleneğine ait yeni uyarlamalar hakkında yapılacak olası araștırmalara ilham vermesi ümit edilmektedir. Damızlık Kızın Öyküsü örneğinde görüldüğü üzere, feminist distopyalardaki bütün tahakküm modelleri özünde kadının düșünce ve eylem alanından uzaklaștırılarak 'beden'e indirgenmesi amacını tașımaktadır. Bu tür anlatılarda kadın, erkeğin soyunu devam ettirmesini sağlama, erkeğe cinsel zevk verme, yeme-içme, temizlik gibi gündelik işleri gerçekleştirme ve erkeğin toplum içindeki saygınlığını destekleme işlevlerini yerine getirmek için fiziksel, cinsel ve duygusal açıdan tahakküm altında tutulmaktadır. Ancak söz konusu tahakküm ilişkilerinin sürdürülmesi özünde sorunludur. Doğrudan baskıya ya da rıza üretimine dayanan herhangi bir tahakküm modelinin devam etmesi için, örnekleri verilen güç gösterileri, gözetim mekanizmaları, cezalandırmalar, ritüeller ve gözdağı verme gibi uygulamalarla sürekli olarak desteklenmesi gerekmektedir. Bu durum, her tahakküm ilişkisinin mutlaka direniş ve karşı çıkma potansiyeli içermesinden kaynaklanmaktadır. Damızlık Kızın Öyküsü'nde de baskılanan kadınların, sınırlı ancak özerk biçimde direniş gösterdiği görülmektedir. Dizideki direniş eylemlerinin çıkış noktasında, kadının kendi kimliğini ve bireyselliğini koruma, dile hâkim olma, bilgiye erişme ve sesini, fikirlerini özgürce duyurabilme cesareti yatmaktadır. Bu bağlamda, tabi grubun direniş olanaklarının incelenmesi, kurulan tahakküm düzeninin zafiyetlerini ve kırılma noktalarını göz önüne sermesi bakımından önemlidir.

Damızlık Kızın Öyküsü dizisi de bilinçlenen ve devamında hak ve özgürlüklerini hiçe sayan sisteme karşı direnişe geçen kadın karakterleri konu almaktadır. Hikâyenin başında June'un tek amacı Gilead'dan kaçabilmektir, hatta sonunda yakalanmasına rağmen bir kere bunu başarır. Ancak, Gilead'daki düzenden kurtulmaya, kızıyla ve eşi Luke'la tekrar beraber olmaya yönelik yoğun arzusuna rağmen June'un bașlangıçta pasif bir konumu benimsediğini söylemek mümkündür. Damızlık olmak üzere eğitim gördükleri Kızıl Merkez'den kaçmayı başaran yakın arkadaşı Moira ya da geriye dönüşlerde izleyiciye tanıtılan annesi 
gibi aktivist ve cesur bir karakter olarak sunulmamaktadır. Bununla birlikte pasif bir kabulleniş ve atalet içindeki June'un olay örgüsü ilerledikçe kaderine razı bir tutsak konumundan, kaçmak yerine kalıp mücadele etmeyi seçen güçlü bir savaşçıya dönüştüğü görülür. Kendi kızı için bir şey yapamıyorsa, Gilead'da doğmuş veya gerçek ailelerinden koparılmış diğer tutsak çocuklar için elinden geleni yapacaktır. Üçüncü sezonun sonu itibariyle bireysel kurtuluş için değil, Gilead rejimi altında acı çeken herkes için mücadele etmeye hazır ve bu doğrultuda öldürmekten bile çekinmeyen, katı ve daha güçlü bir kadın karakter söz konusudur.

\section{Kaynakça}

About Us Mission and Principles. (t.d.). Women's March. Erişim adresi (22 Temmuz 2020): https://womensmarch.com/mission-and-principles

Agonito, R. (1977). History of ideas on woman. New York: G.P. Putnam's Sons.

Atwood, M. (2004). The Handmaid's Tale and Oryx and Crake "in context". PMLA, 119(3), 513-517.

Atwood, M. (2014). Başka dünyalar, bilimkurgu ve hayal gücü. (S. Siral, Çev.). İstanbul: Kolektif Yayınları.

Atwood, M. (2019). Damızlık kızın öyküsü. (S. Altınçekiç ve Ö. Kabakçığlu, Çev.). İstanbul: Doğan Kitap.

Beauvoir, S. (1993). Kadın “ikinci cins” bağımsızlığa doğru. (B. Onaran, Çev.). İstanbul: Payel Yayınevi.

Berktay, F. (2014). Tek tanrılı dinlerde kadın. İstanbul: Metis Yayınları.

Çakır, S. (2009). Osmanlı'da kadınların mekânı, sınırlar ve ihlaller. Alkan, A. (Der.), Cins cins mekân içinde (s. 76-101), İstanbul: Varlık Yayınları.

Foucault, M. (2006). Hapishanenin doğuşu. (M.A. Kılıçbay, Çev.). Ankara: İmge Kitabevi. (Orijinal çalışma basım tarihi 1975).

Gordin, M.D., Tilley H. ve Prakash G. (2017). Mekân ve zamanın ötesinde ütopya ve distopya. Gordin, M.D., Tilley, H. Ve Prakash, G. (Ed.), Ütopya/Distopya tarihsel olasılığın koşulları içinde (s. 7-22), (A. Turan, E. Kartal ve C. Kayalıgil, Çev.), İstanbul: Koç Üniversitesi Yayınları.

Greene, R. (2019). The United States of Gilead? In Robisone-Greene, R. (Ed.), The Handmaid's Tale and philosophy: a womb of one's own (p. 51-58). Chicago: Open Court.

Hesiodos. (2018). Theogonia- Işsler ve günler. (A. Erhat ve S. Eyüboğlu, Çev.). İstanbul: Türkiye İş Bankası Kültür Yayınları.

Holberg, E.A. (2019). Gilead vs. the self. In Robisone-Greene, R. (Ed.), The Handmaid's Tale and philosophy: a womb of one's own (p. 131-138), Chicago: Open Court.

Howells, C.A. (2006). Margaret Atwood's dystopian visions: The Handmaid's Tale and Oryx and Crake. In Howells, C.A. (Ed.), The Cambridge Companion to Margaret Atwood (p. 161-176), Cambridge: Cambridge University Press.

Kolb, L.K. (2019). Gestational totalitarianism. In Robisone-Greene, R. (Ed.), The Handmaid's Tale and philosophy: A womb of one's own (p. 43-50), Chicago: Open Court.

Kumar, K. (2006). Modern zamanlarda ütopya ve karşıütopya. (A. Galip, Çev.). İstanbul: Kalkedon Yayınları.

Manuel, F.E ve Manuel F.P. (1979). Utopian thought in the western world. Cambridge: Belknap Press of Harvard University Press.

Özdemir, M. (2010). Nitel veri analizi: sosyal bilimlerde yöntembilim sorunsalı üzerine bir çalışma. Eskişehir Osmangazi Üniversitesi Sosyal Bilimler Dergisi, 11(1), 323-343. Erişim adresi: https://dergipark.org.tr/tr/pub/ogusbd/issue/10997/131612

Rahte, E.Ç. (2018). The Brand New Testament'ta alternatif bir dünya kurgusu: Babalık krizi ve anaerkil ütopya. sinecine, 9 (2), 7-37.

Roth, S. M. (2005). Trauma: A dystopia of the spirit. In Rüsen, J., Fehr, M. ve Rieger, T.W. (Ed.), Thinking Utopia: Steps into Other Worlds (p. 230-246), New York: Berghahn Books.

Scott, J.C. (2018). Tahakküm ve direniş sanatları gizli senaryolar. (A. Türker, Çev.). İstanbul: Ayrıntı Yayınları. 
Sümer, S. Z. (2017). Sultana'nın rüyası: Bangladeşli bir kadının feminist ütopyası. Selçuk Üniversitesi Edebiyat Fakültesi Dergisi, 38, s. 407-418.

Usta, S. (2005). Platon'dan Jambulos'a antikçağ ütopyalar. İstanbul: Kaynak Yayınları.

Van Dijk, T. (1994). Söylemin yapıları ve iktidarın yapıları. Küçük, M. (Der. ve Çev.), Medya, iktidar, ideoloji içinde (s. 331-398), Ankara: Ark Yayınları.

Yıldırmaz, Y.T. (2005). Ütopyanın kadınları kadınların ütopyası. İstanbul: Sel Yayıncılık.

Yumuşak, F.C. (2012). Ütopya, karşı-ütopya ve Türk edebiyatında ütopya geleneği. Bilig, 61, s. 47-70.

Zimbardo, P. (2007). Şeytan etkisi. İstanbul: Say Yayınları. 